\title{
Effects of Whey Protein on Calcium and Bone Metabolism in Ovariectomized Rats
}

\author{
Yukihiro Takada, Naomichi Kobayashi, Ken Kato, \\ Hiroaki Matsuyama, Masatoshi YaHiro \\ and Seiichiro AOE \\ Snow Brand Milk Products Co., Ltd., Nutritional Science Laboratory, \\ Kawagoe, Saitama 350-11, Japan \\ (Received September 18, 1996)
}

Summary We studied the effects of whey protein (WP) from cow's milk on calcium and bone metabolism in ovariectomized (OVX) rats. Six-week-old female Sprague-Dawley rats were ovariectomized and fed a low-calcium diet $(0.03 \% \mathrm{Ca}, 0.3 \% \mathrm{P})$ for 4 weeks. The OVX rats were divided into three groups and subjected to two experiments: Exp. 1, Cont group (20\% casein, $0.3 \% \mathrm{Ca})$, WP $(1 \%)$ group (19\% casein, $1 \%$ whey protein, $0.3 \% \mathrm{Ca}$ ) and Low-Ca group (20\% casein, $0.03 \% \mathrm{Ca})$; and Exp. 2, Cont group (20\% casein, $0.3 \% \mathrm{Ca}$ ), WP (1\%) group (19\% casein, $1 \%$ whey protein, $0.3 \% \mathrm{Ca}$ ) and W.P $(2 \%)$ group (18\% casein, $2 \%$ whey protein, $0.3 \% \mathrm{Ca}$ ). The rats were fed each experimental diet for 4 weeks. The final body weight, weight gain, food intake and food efficiency showed no significant difference between the Cont and WP $(1 \%, 2 \%)$ groups in Exps. 1 and 2. There were no significant differences in the calcium balance, serum ALP or serum calcitonin levels between the Cont and WP groups in Exp. 1. But the breaking energies of the WP (1\%, 2\%) groups were higher than those of the Cont groups in Exps. 1 and 2. As for the amount of calcium, phosphorus and magnesium in the femur, there were no significant differences between the Cont and WP (1\%, 2\%) groups; however, the amounts of total amino acids in the femur of the WP $(1 \%, 2 \%)$ groups were higher than those of the Cont groups in Exps. 1 and 2. The amounts of proline and hydroxyproline in the femur of the WP $(1 \%, 2 \%)$ groups were also higher than those of the Cont groups in Exps. 1 and 2. These data indicate that the milk whey protein influence in OVX rats is an increase in bone proteins such as collagen and enhanced bone-breaking energy.

Key Words milk, whey protein, ovariectomized (OVX) rats, calcium metabolism, bone metabolism, calcium balance, bone mineral, breaking force, bone protein, hydroxyproline 
There is enormous interest in research to prevent menopause-related bone loss $(1,2)$. It is important to take sufficient dietary nutrients, especially calcium, for the prevention of bone loss. On the other hand, there is a need to develop food components that activate bone formation.

Milk is a good source for calcium absorption and bioavailability $(3,4)$. However, milk is not only an important source of calcium, it is also an excellent source of other nutrients. Whey protein from milk contains excellent nutrients and is produced from whey using ultrafiltration, reverse osmosis, chromatography and dialysis to remove lactose and other components $(5-8)$. Whey is obtained by adding an acid or rennet to milk or non-fat milk and removing the formed coagulate, which is usually produced as a by-product of cheese or casein manufacturing. One hundred milliliters of milk contains $0.55 \mathrm{~g}$ of whey protein, and the major whey proteins are $\alpha$-lactalbumin (58\%), $\beta$-lactoglobulin $(20 \%)$, immunoglobulin (13\%) and serum albumin (7\%) (9). Milk is well known as a safe foodstuff which can be taken for a long time, and is beneficial to human health. Milk has a functional role in the growth of newborns, so milk whey protein may have components that affect bone metabolism. Previously, we found that milk whey protein from cow's milk stimulates the proliferation and differentiation of osteoblastic MC3T3-E1 cells $(10,11)$. In this study, we therefore examined the effects of whey protein from cow's milk on calcium and bone metabolism using ovariectomized (OVX) rats.

\section{MATERIALS AND METHODS}

Animals and diet. Five-week-old female Sprague-Dawley rats (Charles River Inc., Japan) were housed in individual wire cages in a temperature- and humiditycontrolled room $\left(23 \pm 1{ }^{\circ} \mathrm{C}\right.$ and $60 \pm 5 \%$ relative humidity, respectively) with a 12 $\mathrm{h}$ light/dark cycle. Under anesthesia, the 21 rats were ovariectomized as described by D'Amour et al. (12) at 6 weeks of age. The ovariectomized rats were fed a low-calcium (0.03\%) diet ad libitum for 4 weeks. After 4 weeks of feeding, the OVX rats were separated into three experimental groups and subjected to two experiments: Exp. 1, Cont group (20\% casein, 0.3\% Ca), WP (1\%) group (19\% casein, $1 \%$ whey protein, $0.3 \% \mathrm{Ca}$ ) and Low-Ca group (20\% casein, $0.03 \% \mathrm{Ca}$ ); and Exp. 2, Cont group (20\% casein, $0.3 \% \mathrm{Ca})$, WP (1\%) group (19\% casein, $1 \%$ whey protein, $0.3 \% \mathrm{Ca}$ ) and WP (2\%) group (18\% casein, $2 \%$ whey protein, $0.3 \% \mathrm{Ca}$ ) of seven rats per group. The rats were fed each experimental diet for 4 weeks (Table 1). Whey protein from cow's milk was prepared from whey protein concentrate (WPC) by dialysis only. The WPC was purchased from the New Zealand Dairy Board (Wellington, New Zealand). All rats were given deionized water ad libitum. The phosphorus and magnesium contents were identical (Table 1). The amino acid compositions of protein in the diets are shown in Table 2.

Calcium balance study. A two-part balance study was performed in the first and third weeks of the experimental periods. All rats were housed in metabolic 
Table 1. Composition of diets (\%). ${ }^{1,2}$

\begin{tabular}{|c|c|c|c|c|}
\hline & \multicolumn{4}{|c|}{ Group } \\
\hline & Cont-OVX & WP (1\%)-OVX & WP (2\%)-OVX & Low-Ca-OVX \\
\hline Casein & 20.00 & 19.00 & 18.00 & 20.00 \\
\hline Whey protein ${ }^{3}$ & - & 1.00 & 2.00 & - \\
\hline Sucrose & 51.06 & 51.09 & 51.11 & 51.78 \\
\hline Corn starch & 15.00 & 15.00 & 15.00 & 15.00 \\
\hline Cellulose & 5.00 & 5.00 & 5.00 & 5.00 \\
\hline Corn oil & 5.00 & 5.00 & 5.00 & 5.00 \\
\hline DL-Methionine & 0.30 & 0.30 & 0.30 & 0.30 \\
\hline Choline chloride & 0.20 & 0.20 & 0.20 & 0.20 \\
\hline Vitamin mix & 1.00 & 1.00 & 1.00 & 1.00 \\
\hline $\mathrm{CaCO}_{3}$ & 0.75 & 0.74 & 0.73 & 0.08 \\
\hline $\mathrm{KH}_{2} \mathrm{PO}_{4}$ & 1.32 & 1.31 & 1.30 & 1.32 \\
\hline $\mathrm{NaCl}$ & 0.25 & 0.24 & 0.24 & 0.25 \\
\hline $\mathrm{MgO}$ & 0.08 & 0.08 & 0.08 & 0.08 \\
\hline Basal mixture ${ }^{4}$ & 0.04 & 0.04 & 0.04 & 0.04 \\
\hline
\end{tabular}

${ }^{1}$ Basal composition of experimental diets was based on AIN-76 (American Institute of Nutrition) formulation.

${ }^{2}$ Total calcium, phosphorus, sodium, potassium and magnesium concentrations were $300,300,100,380$ and $50 \mathrm{mg} / 100 \mathrm{~g}$, respectively.

${ }^{3}$ One gram of whey protein contained calcium $(2.9 \mathrm{mg})$, phosphorus $(2.9 \mathrm{mg})$, sodium $(2.4 \mathrm{mg})$, potassium $(4.5 \mathrm{mg})$ and magnesium $(0.4 \mathrm{mg})$.

${ }^{4}$ Basal mixture composition was based on the AIN-76 Mineral Mix $\left(\mathrm{MnCO}_{3}: 12 \mathrm{mg}\right.$, $\mathrm{FeC}_{6} \mathrm{H}_{5} \mathrm{O}_{7} \cdot x \mathrm{H}_{2} \mathrm{O}: 21 \mathrm{mg}, 70 \% \mathrm{ZnO}: 5.6 \mathrm{mg}, 55 \% \mathrm{CuCO}_{3}: 1.1 \mathrm{mg}, \mathrm{KIO}_{3}: 0.035 \mathrm{mg}$, $\left.\mathrm{Na}_{2} \mathrm{SeO}_{3} \cdot 5 \mathrm{H}_{2} \mathrm{O}: 0.035 \mathrm{mg}, \mathrm{CrK}\left(\mathrm{SO}_{4}\right)_{2} \cdot 12 \mathrm{H}_{2} \mathrm{O}: 1.9 \mathrm{mg}\right)$.

cages for 5 days and subjected to a calcium balance study. During this period, food intake was monitored and feces and urine were collected.

The absorption and retention ratios of calcium were each determined by the following equations:

Apparent $\mathrm{Ca}$ absorption rate (\%) $=(\mathrm{Ca}$ intake - Fecal $\mathrm{Ca}$ excretion $) / \mathrm{Ca}$ intake,

Ca Retention (mg/day) $=\mathrm{Ca}$ intake $-($ Fecal $\mathrm{Ca}$ excretion + Urinary $\mathrm{Ca}$ excretion $)$

and

Ca Retention rate $(\%)=($ Retention $/ \mathrm{Ca}$ intake $) \times 100$.

Determination of calcium. Diets and feces were first dried and micropulverized. The micropulverized samples were then ashed at $550^{\circ} \mathrm{C}$ for $48 \mathrm{~h}$. The ashed samples were dissolved in $1 \mathrm{~N}^{\mathrm{HNO}_{3}}$ and diluted with distilled water. The amount of calcium in the diets, feces, and urine were determined by ICP-Atomic Emission Spectrometry (ST-3000, LEEMAN LABS; MA, USA).

Determination of breaking force of femur. Four weeks after the feeding of 
Table 2. Amino acid composition of protein in diets (\% of protein).

\begin{tabular}{lrrrrr}
\hline & & & \multicolumn{3}{c}{ Group } \\
\cline { 3 - 6 } & Casein & WP & $\begin{array}{c}\text { Cont-OVX } \\
\text { Low-Ca-OVX }\end{array}$ & WP (1\%)-OVX & WP (2\%)-OVX \\
\hline Asp & 6.84 & 10.34 & 6.84 & 7.02 & 7.19 \\
Thr & 4.11 & 7.16 & 4.11 & 4.26 & 4.42 \\
Ser & 5.72 & 5.39 & 5.72 & 5.70 & 5.69 \\
Glu & 19.99 & 16.19 & 19.99 & 19.80 & 19.61 \\
Pro & 10.94 & 6.79 & 10.94 & 10.73 & 10.53 \\
Gly & 1.88 & 1.94 & 1.88 & 1.88 & 1.89 \\
Ala & 3.01 & 5.36 & 3.01 & 3.13 & 3.25 \\
Cys & 0.06 & 0.33 & 0.06 & 0.07 & 0.09 \\
Val & 5.83 & 5.70 & 5.83 & 5.82 & 5.82 \\
Met & 2.79 & 2.17 & 2.79 & 2.76 & 2.73 \\
Ile & 4.49 & 6.02 & 4.49 & 4.57 & 4.64 \\
Leu & 8.87 & 10.81 & 8.87 & 8.97 & 9.06 \\
Tyr & 5.30 & 3.16 & 5.30 & 5.19 & 5.09 \\
Phe & 4.89 & 3.64 & 4.89 & 4.83 & 4.77 \\
Lys & 7.39 & 8.80 & 7.39 & 7.46 & 7.53 \\
His & 2.77 & 1.83 & 2.77 & 2.72 & 2.68 \\
Trp & 1.58 & 1.71 & 1.58 & 1.59 & 1.59 \\
Arg & 3.54 & 2.64 & 3.54 & 3.50 & 3.45 \\
\hline
\end{tabular}

experimental diets, the femoral bones were isolated, and the muscles and connective tissues carefully removed. The breaking strength and breaking energy of the femoral diaphysis (the center of the femur) was determined using a three-point bending rheolometer (RX-1600, Aitechno, Japan) by the method of Ezawa et al. (13). The way of measurement and determination of breaking strength and energy are shown in Fig. 1. The measurement conditions were as follows: plunger speed, $100 \mathrm{~mm} / \mathrm{min}$; and load range, $40.0 \mathrm{~kg}$.

Femoral mineral (calcium, magnesium, phosphorus) and amino acid (hydroxyproline, proline) content. All femurs were lyophilized for $72 \mathrm{~h}$. The right femurs were dissolved in $6 \mathrm{~N} \mathrm{HCl}$ and hydrolysed at $120^{\circ} \mathrm{C}$ for $24 \mathrm{~h}$. The samples were analyzed by an amino acid analyzer. The left femoral bones were ashed at $550^{\circ} \mathrm{C}$ for $48 \mathrm{~h}$, dissolved in $1 \mathrm{~N} \mathrm{HNO}_{3}$ and analyzed by ICP-Atomic Emission Spectrometry.

Statistical analysis. Statistical analysis was done by analysis of variance and Tukey's multiple-range test. Differences in mean values between the groups were considered significant at $p<0.05$.

\section{RESULTS}

The results of final body weight, body weight gain, food intake and food 

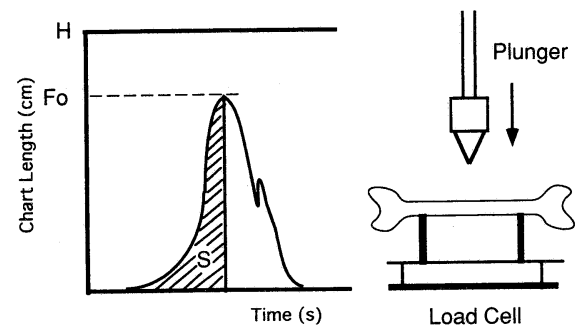

$F_{\max }$; Full Scale of Load Cell $=40 \mathrm{~kg}$

$\mathrm{H}$; Chart Full Length $(\mathrm{cm})=25 \mathrm{~cm}$

CL; Weight/cm Chart

$\alpha$; Chart Speed $\alpha \mathrm{cm} / \mathrm{min}$

$\beta$; Plunger Speed $\beta \mathrm{cm} / \mathrm{min}$

Breaking Strength $=\mathrm{F}_{0} \times 980 \times \mathrm{CL}$

(dyn) $\quad(\mathrm{cm}) \quad\left(\mathrm{cm} / \mathrm{s}^{2}\right) \quad(\mathrm{kg} / \mathrm{cm})$

Breaking Energy $=\mathrm{S} \times \mathrm{Cc} \times \mathrm{CL} \times 980$

$(\mathrm{erg}) \quad\left(\mathrm{cm}^{2}\right)(\mathrm{kg} / \mathrm{cm}) \quad\left(\mathrm{cm} / \mathrm{s}^{2}\right)$

$\mathrm{Cc}=\beta / \alpha$

$\mathrm{CL}=1 / \mathrm{H} \times \mathrm{F}_{\max } \times 10^{3}$

$(\mathrm{kg} / \mathrm{cm})(1 / \mathrm{cm})(\mathrm{kg})$

Fig. 1. Measurement of breaking strength and breaking energy of femur by rheolometer MAX (RX-1600).

Table 3. Effects of whey protein and low-calcium diets on body weight, food intake and food efficiency from 10 to 14 weeks.

\begin{tabular}{lccc}
\hline & \multicolumn{3}{c}{ Exp. 1 group } \\
\cline { 2 - 4 } & Cont-OVX & WP (1\%)-OVX & Low-Ca-OVX \\
\hline Final weight (g) & $377 \pm 28.0$ & $380 \pm 18.5$ & $368 \pm 36.3$ \\
Body weight gain (g) & $82.1 \pm 15.8^{\mathrm{a}}$ & $85.6 \pm 7.8^{\mathrm{a}}$ & $70.3 \pm 14.9^{\mathrm{b}}$ \\
Food intake (g) & $586 \pm 28.3$ & $589 \pm 30.3$ & $570 \pm 79.9$ \\
Food efficiency & $0.14 \pm 0.02$ & $0.15 \pm 0.01$ & $0.13 \pm 0.02$ \\
\hline & \multicolumn{3}{c}{ Exp. 2 group } \\
\cline { 2 - 4 } & Cont-OVX & WP $(1 \%)-O V X$ & WP $(2 \%)-O V X$ \\
\hline Final weight (g) & $382 \pm 25.2$ & $385 \pm 21.2$ & $389 \pm 24.3$ \\
Body weight gain (g) & $80.7 \pm 10.4$ & $83.9 \pm 8.6$ & $87.1 \pm 10.1$ \\
Food intake (g) & $607 \pm 41.2$ & $611 \pm 34.5$ & $605 \pm 32.7$ \\
Food efficiency & $0.13 \pm 0.02$ & $0.14 \pm 0.02$ & $0.14 \pm 0.02$ \\
\hline
\end{tabular}

Values are $\mathbf{M} \pm \mathrm{SD}(n=7)$.

Different letters denote means that are significantly different $(p<0.05)$. 
efficiency are shown in Table 3. The final body weight, weight gain, food intake and food efficiency were not significantly different between the Cont and WP (1\%, 2\%) groups in Exps. 1 and 2. The results of the balance study performed in the first and third weeks of the experimental period are shown in Table 4. Calcium absorption rates, calcium retention and retention rate at 13 weeks of age (beginning of the third week of the study period) decreased slightly compared with those measured at 11 weeks of age (end of the first week). However, the calcium balance of the WP groups showed no significant difference among the OVX groups in Exp. 1. The results of the serum ALP activity and serum calcitonin level are shown in Fig. 2. The serum ALP level of the Low-Ca group was higher than that of the Cont group,

Table 4. Effect of whey protein and low-calcium diets on apparent calcium absorption rate, calcium retention and retention rate in OVX rats.

\begin{tabular}{lccc}
\hline & \multicolumn{3}{c}{ Group } \\
\cline { 2 - 4 } & Cont-OVX & WP (1\%)-OVX & Low-Ca-OVX \\
\hline Apparent Ca absorption rate (\%) & & & \\
$\quad 11 \mathrm{wk}$ & $78.6 \pm 4.14^{\mathrm{a}}$ & $78.4 \pm 3.67^{\mathrm{a}}$ & $95.5 \pm 1.56^{\mathrm{b}}$ \\
$\quad 13 \mathrm{wk}$ & $66.1 \pm 3.50^{\mathrm{a}}$ & $67.2 \pm 2.80^{\mathrm{a}}$ & $94.8 \pm 3.27^{\mathrm{b}}$ \\
Ca retention (mg) & & & \\
$\quad 11 \mathrm{wk}$ & $60.3 \pm 3.18^{\mathrm{a}}$ & $61.3 \pm 4.91^{\mathrm{a}}$ & $2.63 \pm 0.45^{\mathrm{b}}$ \\
$\quad 13 \mathrm{wk}$ & $53.2 \pm 2.88^{\mathrm{a}}$ & $55.4 \pm 2.70^{\mathrm{a}}$ & $2.34 \pm 0.26^{\mathrm{b}}$ \\
Ca retention rate (\%) & & & \\
$11 \mathrm{wk}$ & $76.6 \pm 3.70^{\mathrm{a}}$ & $76.2 \pm 3.70^{\mathrm{a}}$ & $93.5 \pm 1.48^{\mathrm{b}}$ \\
$13 \mathrm{wk}$ & $64.2 \pm 3.58^{\mathrm{a}}$ & $65.4 \pm 3.06^{\mathrm{a}}$ & $92.9 \pm 3.32^{\mathrm{b}}$ \\
\hline
\end{tabular}

Values are $\mathrm{M} \pm \mathrm{SD}(n=7)$.

Different letters denote means that are significantly different $(p<0.05)$.
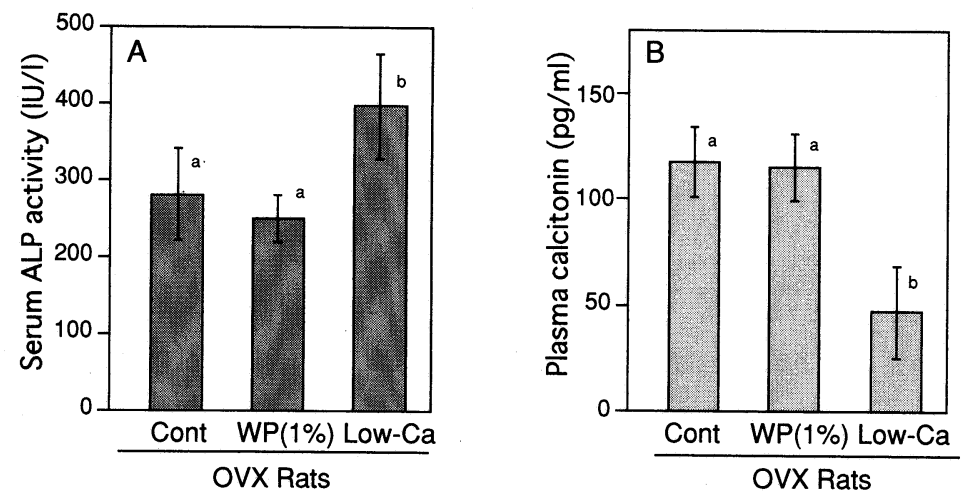

Fig. 2. Effects of whey protein and low-calcium diets on serum ALP activity and plasma calcitonin level in OVX rats at $14 \mathrm{wk}$ of age in Exp. 1. A, Serum ALP activity; B, plasma calcitonin level. The results are expressed as $\mathbf{M} \pm \mathbf{S D}(n=7)$. Different letters denote means that are significantly different $(p<0.05)$. 
while there was no significant difference between the Cont and WP groups in Exp. 1.

The results of breaking strength and breaking energy are shown in Figs. 3 and 4. There was no significant difference in breaking strength between the Cont and WP $(1 \%, 2 \%)$ groups, but the breaking energies of the WP $(1 \%, 2 \%)$ groups were higher than those of the Cont groups in Exps. 1 and 2. The results of the amounts of calcium, phosphorus and magnesium in the femur are shown in Table 5, and the results of the amounts of total amino acid in the femur are shown in Fig. 5. As for the amounts of calcium, phosphorus, and magnesium, there were no significant differences between the Cont and WP $(1 \%, 2 \%)$ groups in Exps. 1 and 2.
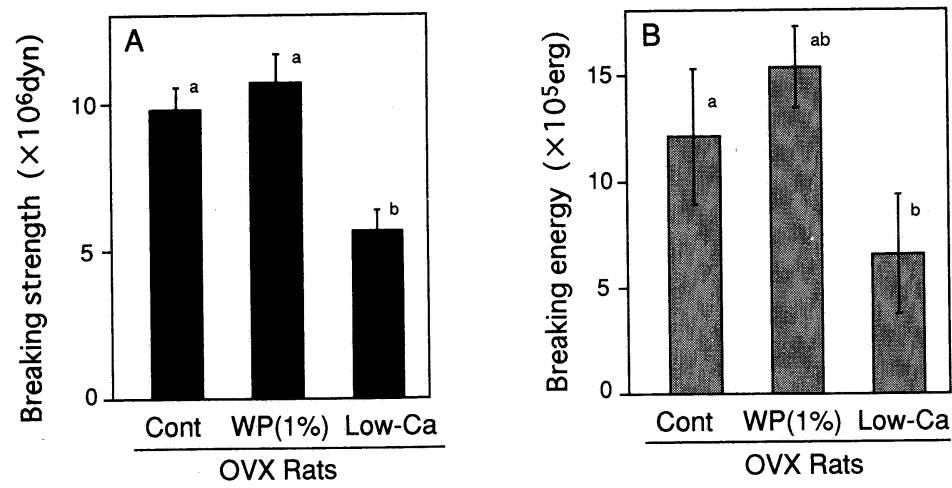

Fig. 3. Effects of whey protein and low-calcium diets on breaking strength and breaking energy of femur in OVX rats at $14 \mathrm{wk}$ of age in Exp. 1. A, Breaking strength; B, breaking energy. The results are expressed as $\mathrm{M} \pm \mathrm{SD}(n=14)$. Different letters denote means that are significantly different $(p<0.05)$.
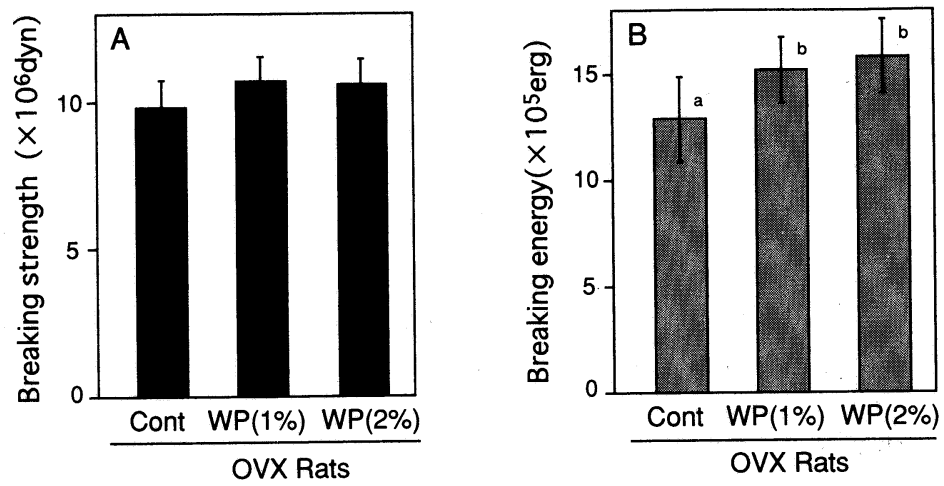

Fig. 4. Effects of whey protein diets on breaking strength and breaking energy of femur in OVX rats at $14 \mathrm{wk}$ of age in Exp. 2. A, Breaking strength; B, breaking energy. The results are expressed as $\mathbf{M} \pm \mathbf{S D}(n=14)$. Different letters denote means that are significantly different $(p<0.05)$. 
Table 5. Effect of whey protein and low-calcium diets on the amounts of calcium, phosphorus and magnesium in the femur using OVX rats.

\begin{tabular}{lccc}
\hline & \multicolumn{3}{c}{ Exp. 1 group } \\
\cline { 2 - 4 } & Cont-OVX & WP (1\%)-OVX & Low-Ca-OVX \\
\hline Femur calcium (mg) & $123 \pm 11.2^{\mathrm{a}}$ & $124 \pm 14.4^{\mathrm{a}}$ & $60.9 \pm 7.14^{\mathrm{b}}$ \\
Femur phosphorus (mg) & $57.2 \pm 5.76^{\mathrm{a}}$ & $58.3 \pm 7.06^{\mathrm{a}}$ & $28.4 \pm 3.89^{\mathrm{b}}$ \\
Femur magnesium (mg) & $2.26 \pm 0.23^{\mathrm{a}}$ & $2.36 \pm 0.29^{\mathrm{a}}$ & $1.02 \pm 0.15^{\mathrm{b}}$ \\
\hline & \multicolumn{3}{c}{ Exp. 2 group } \\
\cline { 2 - 4 } & Cont-OVX & WP (1\%)-OVX & WP (2\%)-OVX \\
\hline Femur calcium (mg) & $120 \pm 13.2$ & $123 \pm 10.9$ & $125 \pm 11.3$ \\
Femur phosphorus (mg) & $57.5 \pm 6.09$ & $58.1 \pm 5.36$ & $59.6 \pm 5.71$ \\
Femur magnesium (mg) & $2.29 \pm 0.22$ & $2.33 \pm 0.19$ & $2.35 \pm 0.24$ \\
\hline
\end{tabular}

Values are $\mathbf{M} \pm \mathrm{SD}(n=7)$.

Different letters denote means that are significantly different $(p<0.05)$.
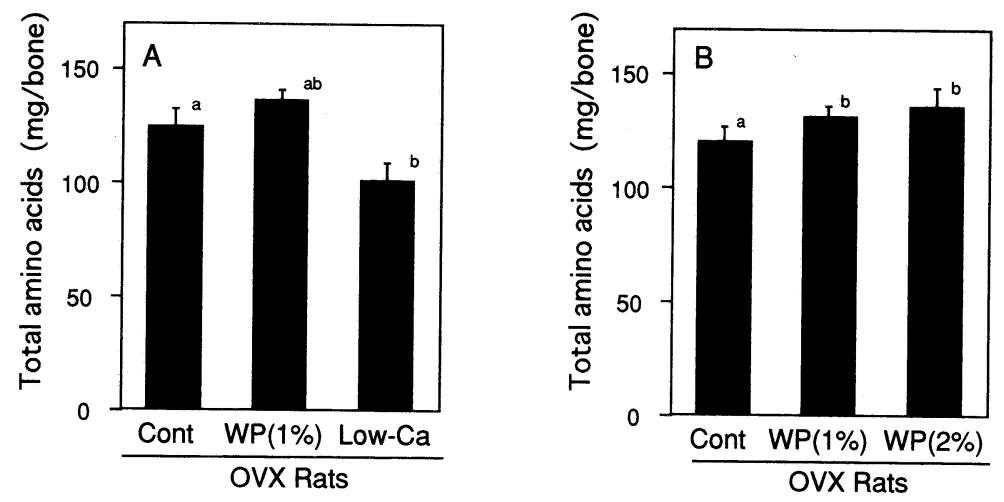

Fig. 5. Effects of whey protein and low-calcium diets on total amino acids in the femur using OVX rats at $14 \mathrm{wk}$ of age. A, Exp. 1; B, Exp. 2. The results are expressed as $\mathbf{M} \pm \mathrm{SD}(n=7)$. Different letters denote means that are significantly different $(p<0.05)$.

However, the amounts of total amino acids in the femur of the WP (1\%, 2\%) groups were higher than those of the Cont groups in Exps. 1 and 2. The results of the amounts of proline and hydroxyproline in the femur are shown in Figs. 6 and 7. The amounts of proline and hydroxyproline of the WP $(1 \%, 2 \%)$ groups were also higher than those of the Cont groups in Exps. 1 and 2.

\section{DISCUSSION}

In this study, we examined the effect of whey protein on calcium and bone 

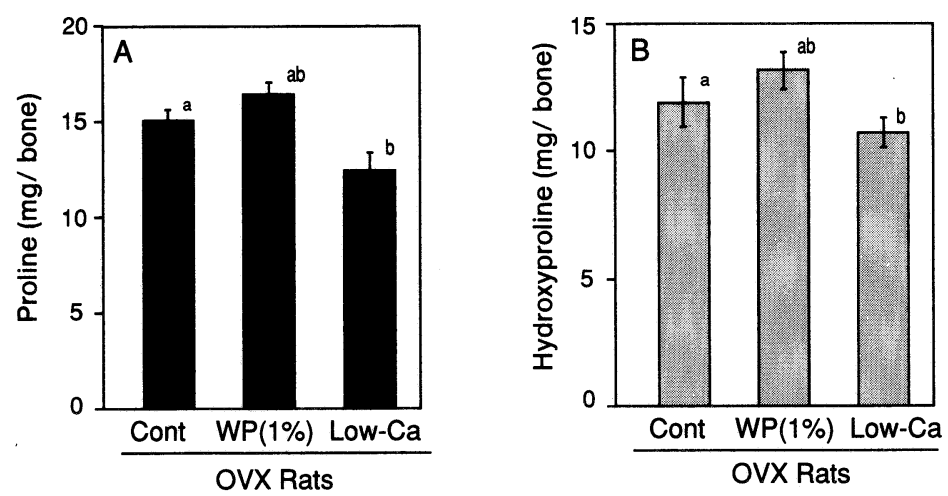

Fig. 6. Effects of whey protein and low-calcium diets on proline and hydroxyproline in the femur using OVX rats at $14 \mathrm{wk}$ of age in Exp. 1. A, Femur proline; $\mathbf{B}$, femur hydroxyproline. The results are expressed as $\mathbf{M} \pm \mathbf{S D}(n=7)$. Different letters denote means that are significantly different $(p<0.05)$.
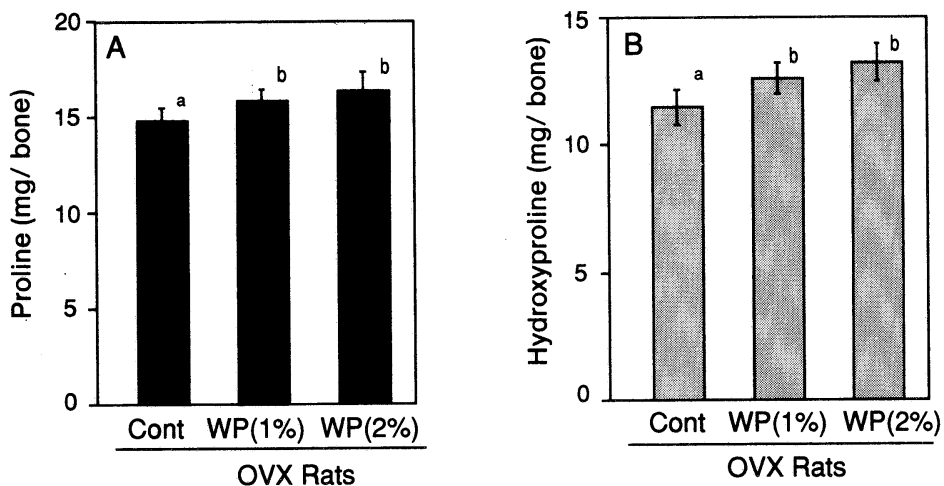

Fig. 7. Effects of whey protein diets on proline and hydroxyproline in the femur using OVX rats at $14 \mathrm{wk}$ of age in Exp. 2. A, Femur proline; B, femur hydroxyproline. The results are expressed as $\mathbf{M} \pm \mathbf{S D}(n=7)$. Different letters denote means that are significantly different $(p<0.05)$.

metabolism using ovariectomized rats. The feeding of a normal diet to the ovariectomized rats that had been fed a low-calcium diet caused a $48 \%$ increase in bone mineral density within 30 days $(13,14)$. The rats fed on the whey proteinsupplemented diet showed a significant increase in bone strength and hydroxyproline and proline content. The results of this study have demonstrated that whey protein influences bone metabolism by increasing the amount of bone protein such as collagen and enhancing bone-breaking energy.

We first examined a calcium balance study and some serum parameters of the calcium metabolism because the enhancement of calcium absorption and calcium retention might cause an alternation of the bone calcium metabolism in rats, 
resulting in an elevation of calcium content and eventually an increase in resistance against breakage (13-15). In the calcium balance study, we examined the apparent calcium absorption rate, calcium retention and calcium retention rate in the first and third weeks of experimental diet feeding. Previously, we reported the balance study of various calcium compounds using normal male rats. In spite of the lower calcium level $(300 \mathrm{mg})$, calcium retention at 13 weeks of age in this study was higher than that of a previous study (43 mg/day; Ca $600 \mathrm{mg}, \mathrm{P} 460 \mathrm{mg}$ ) (16). The reason for this difference is thought to be that the demand for calcium was high because the osteoporotic rats recovered from the state of osteoporosis to the normal state immediately. However, the apparent calcium absorption rate, calcium retention and retention rate of the WP groups were not significantly different from the Cont groups. Moreover, the serum ALP levels of the Low-Ca groups were higher than those of the Cont groups. The high-risk state of osteoporotic rats given low-calcium diets is associated with the high serum ALP levels. The serum bone-type ALP levels in the OVX groups were increased, and this enzyme may be released in a large quantity from the osteoblast membrane into serum in OVX animals, similar to those in rickets or osteomalacia (17). These results show that this model is useful for evaluation of the calcium metabolism. However, there was no clear difference in serum ALP activity between the Cont and WP groups. We also measured plasma calcitonin because there was a correlation between plasma calcitonin and calcium retention (16). However, there was no difference in the calcitonin level between the Cont and WP groups.

However, the breaking energies of the femur were significantly higher in the WP (1\%, 2\%) groups as compared to those of the Cont groups in Exps. 1 and 2. Breaking strength is the maximum power that is required to break bone by the three-point bending method. On the other hand, breaking energy is an integration value of power that is required to make a break. It is thought that breaking strength is a momentary and maximum power, whereas breaking energy is the overall power that is required to make a break. That is, it is thought that breaking strength reflects both bone mineral and bone proteins such as collagen, whereas breaking energy mainly reflects bone proteins such as collagen. In this regard, it is thought that the enhancement of bone strength due to the intake of whey protein causes an alteration of bone metabolism, resulting in an elevation of bone protein. Mature bone matrix is a complex of highly mineralized tissue with a structural framework including bone proteins. Bone proteins consist of mainly collagen and a small number of non-collagenous proteins and glycoproteins. The amounts of total amino acids in the femur of the WP $(1 \%, 2 \%)$ groups increased as compared to those of the Cont groups in Exps. 1 and 2. The amounts of proline and hydroxyproline in the femur of the WP $(1 \%, 2 \%)$ groups also increased as compared to those of the Cont groups in Exps. 1 and 2. From these results, it is thought that the amounts of femur proline and hydroxyproline, which are typical amino acids in collagen, were increased by the intake of whey protein. An increase in the bone-breaking energy from whey protein might result from an increase in 
bone proteins such as collagen, not the action of an increase in bone mineral.

In our previous study, whey protein stimulated the cell growth and promotion of hydroxyproline content in osteoblastic MC3T3-E1 cells (9). Using rat everted gut sac, the inner solution of a whey protein fraction, pepsin-digested and pepsin/ pancreatin-digested fractions also stimulated cell growth in osteoblastic MC3T3-E1 cells (9). However, we could not demonstrate the relationship between these results in vivo and previous results in vitro. Further studies are required to determine the mechanism. In conclusion, it is suggested that whey protein has effect on bone metabolism.

We would like to express our appreciation to Dr. Ikuko Ezawa and Dr. Chie Igarashi for their helpful suggestions and support.

\section{REFERENCES}

1) Kanis JA, Geusens P, Christiansen C. 1991. Guidelines for clinical trials in osteoporosis. Osteoporosis Int 1: 182-188.

2) Seeman E, Cooper M, Hopper JL. 1988. Effect of early menopause on bone mass in normal women and patients with osteoporosis. Am J Med 85: 213-216.

3) Poneros-Schneier AG, Erdman JW Jr. 1982. Bioavailability of calcium from sesame seeds, almond powder, whole wheat bread, spinach and nonfat dry milk in rats. $J$ Food Sci 54: 150-153.

4) Kansal VK, Chaudhary S. 1982. Biological availability of calcium, phosphorus and magnesium from dairy products. Milchwissenschaft 37: 261-263.

5) Hiddink J, de Bore R, Romijn DJ. 1978. Removal of milk salts during ultrafiltration of whey and buttermilk. Neth Milk Dairy J 32: 80-93.

6) Rosenthal I. 1991. Conversion of milk to products. In: Milk and Dairy Products (Rosenthal I, ed), p 135-138. Verlagsgesellschaft mbH, Weinheim.

7) Glover FA. 1971. Concentration of milk by ultrafiltration and reverse osmosis. $J$ Dairy Res 38: 373-379.

8) Skudder PJ. 1985. Evaluation of a porous silica-based ion-exchange medium for the production of protein fractions from rennet- and acid-whey. J Dairy Res 52: 167-168.

9) Ito T. 1991. Science of breast milk. New Food Ind 33(3): 73-80.

10) Takada Y, Yahiro M, Nakajima I. 1993. Effect of milk components on calcium absorption and bone metabolism. In: Characterization of Milk Component and Health (Yamauchi K, Imamura T, Morita T, eds), p. 171-185. Kouseikan, Tokyo.

11) Takada Y, Aoe S, Kumegawa M. 1996. Whey protein stimulates cell proliferation and differentiation in osteoblastic MC3T3-E1 cells. Biochem Biophys Res Commun 223: 445-449.

12) D'Amour FE, Blood FR, Belden DA. 1965. Manual for Laboratory Work in Mammalian Physiology, 3rd ed. University of Chicago Press, Chicago.

13) Ezawa I, Okada R, Nozaki Y, Ogata E. 1979. Breaking-properties and ash contents of femur of growing rats fed a low calcium diet. J Jpn Soc Nutr Food Sci 32: 329-335.

14) Goda T, Suruga K, Takase S, Ezawa I, Hosoya N. 1995. Dietary maltitol increases calcium content and breaking force of femoral bone in ovariectomized rats. $J$ Nutr 
125: 2869-2873.

15) Jiu LJ, Morikawa N, Omi N, Ezawa I. 1994. The effect of Tochubark on bone metabolism in the rat model with ovariectomized osteoporosis. J Nutr Sci Vitaminol 40: 261-273.

16) Takada Y, Suetake N, Yahiro M, Ahiko K, Nakajima I. 1990. Bioavailability of various dietary calcium compounds. Snow Brand Milk Prod Co Ltd Inst Rep 91: 7584.

17) Goseki SM, Omi N, Yamamoto A, Oida S, Ezawa I, Sasaki S. 1996. Ovariectomy decreases osteogenetic activity in rat bone. J Nutr Sci Vitaminol 42: 55-67. 